\title{
The essence and basic product selling strategies in recreation and health tourism
}

\author{
Oleksandr Hladkyi ${ }^{1, *}$, Svitlana Sakhno ${ }^{2}$, Olena Khadzhynova ${ }^{2}$, Alla Dakal ${ }^{3}$, and Larysa \\ Kapranova $^{2}$ \\ ${ }^{1}$ Kyiv National University of Trade and Economics Ukraine, 19, Kyoto str. 02156 Kyiv, Ukraine \\ ${ }^{2}$ Pryazovskyi State Technical University, Universytets'ka street 7, 87555 Mariupol, Ukraine \\ ${ }^{3}$ Private Higher Education Institution "Interregional Academy of Personnel Management", Department \\ of Public Administration, 2 Frometivska str., 03039 Kyiv, Ukraine
}

\begin{abstract}
This paper deals with basic product selling strategies in recreation and health tourism investigations. The theoretical principles of formation and selling the product of recreational tourism are disclosed. The health and recreational tourism definition as an object of scientific research is proposed. The worldwide management practice of formation on the product of health and recreational tourism is considered. Health tourism investigates different elements of health treatment system as well as investigates basic concepts of health treatment in tourism. These directions of recreation and health treatment sciences investigations became more urgent nowadays and content the main scientific aim of this article. Health treatment system is a system of social and natural sciences that investigates health reproduction by restoring of their essential powers; investigates conditions, causes, characteristics, mechanisms and drivers of the recovery process at different stages; investigates laws and principles of formation and development of recreation systems as well as their interrelations with other elements of social life and production in resort systems. The purpose of the research is to study theoretic and practical aspects of the product selling strategies in health and recreational tourism as well as proposals for its improvement.
\end{abstract}

\section{Introduction}

Nowadays, the tourism business occupies a considerable part of the world market. One of the major factors there is the quality of service and granting of services by the companies in the sphere of tourism during trips. And this factor depends on the rightness of forming a product policy.

Actuality of the research in the thesis is to improve the quality of resort's product policy. Each of them survives and thrives due to the fact that more effectively, compared to competitors, meets the needs of certain consumer's groups. To do this, managers of commercial enterprises have to make complex decisions regarding the strategies development, selection and formation of the trade range, pricing, goods presentation and its

\footnotetext{
*Corresponding author: alexander.gladkey@gmail.com
} 
promotion in the store. These actions set taken by trade enterprises to meet the needs of buyers and influence their purchasing decisions, - is the trade range management subject.

In a market economy, assortment policy is an important part of the overall trading strategy. Assortment policy is a predetermined course of action or deliberate principles by which the product policy formation is carried out. The goods assortment is understood as a set of related goods, which combines during the sale can bring an additional effect to the enterprise. Entrepreneurs in the range formation are guided primarily by the desire to make a profit. On the one hand, the assortment expansion provides the enterprise with an increase in turnover and profits, on the other, it inevitably increases inventories and slows down the turnover of funds, and this increases distribution costs and reduces profits.

Product policy formation at the enterprise covers a wide area of activity, affecting strategic planning at all stages of the company's development, and involving many departments on the enterprise. When forming the assortment policy, the company not only has to optimize the value of the completeness and assortment's stability, but also implement a pricing policy, determine cost-effective nomenclature product groups, and look for profitable sales markets for them.

Thus, the product's policy formation main objectives are: ensuring the compliance of the company's services with the nature of demand; optimization of provided services based on demand; analysis of the service sales and profitability; optimal markup determination; accommodation and nutrition planning; events organization to promote the services provided; ensuring economic efficiency (profitability) of the resort.

\section{Methods and object}

The methodological basis of this study is a general scientific dialectical method. The main research methods are: the method of literary, illustrative, descriptive, analytical and scientific synthesis.

Object of health tourism is a health treatment system as an objective and social formation that includes patients, natural systems, technical infrastructure, service sector, production sector, labor as well as settlement system. Recreation, physical and intellectual people rejuvenation is one of the main tourism goals. Recreational tourism has become a mass phenomenon. Its driving force - to relieve civilizational stress - is active rest, wellbeing creation, working capacity restoration, health preservation and improvement. It included a variety of tourism activities, from exploring distant and exotic places or enjoying a seaside holiday, participating in cultural programs and various forms of entertainment. Recreational tourism shares many characteristics with both health and medical tourism and health tourism.

\section{Results}

\subsection{Recreation and Health Tourism Essence}

Health tourism investigates different aspects and objective principles of health treatment system and their subsystems development as well as investigates basic concepts of health treatment in tourism. Health tourism investigates the basic scientific categories that disclose essence and development principles of health treatment systems.

Health tourism resources are objects and effects with natural and anthropogenic genesis that are favorable for Health tourism by their specific qualitative and quantitative parameters. They include material basis for the territorial organization of rehabilitation and 
human treatment and also for the specialization of different areas (centers) of Health tourism which provide high indices of effectiveness.

Health tourism conditions include a number of environmental components and features that influence on development of Health tourism but not included into material base of Health tourism system (landscape, climatic features, mineral water sources, biodiversity, various resources for sport development, etc.).

Health tourism territory is specific territory that is used for human treatment. Health tourism territory is used for short-term (parks, city green areas, water etc.) and long -term Health tourism (coastal areas, medical spa complexes etc.).

Health tourism object is a limited area used for Health tourism (forest lawns, natural objects, coastal areas, etc.). Health tourism capacity is ability to provide psychophysiological comfort, sport and Health treatment activities for patients that lead to no-degradation of natural-territorial or cultural complexes as well as to slow deterioration of social equipment.

Health tourism loading is a number of direct human influences on the natural territorial complex, primarily on vegetation growth (trampling, soil compaction, destruction of biomass, etc.). Recreation is a specific process of human physical, mental and neuropsychiatric energy restoration that provides the system of specific actions and occurred in free time. Leisure is off time when person is free from any business activities. Relaxation is human energy recuperation through activity modification or interruption with a short rest.

There are different branches of health tourism: Wellness and SPA Tourism; Eye Treatment and Ophthalmology Tourism; Fitness Tourism; Treatment of Drug Addiction; Bone Marrow Transplantation, Rheumatology and Orthopedic Surgery Tourism; Cancer Treatment Tourism; Cardiology Tourism; Cosmetic Surgery and Dermatology Tourism; Dentistry Tourism; Family Medicine Tourism; Neurologic and Psychiatric Tourism; Pulmonology and Otolaryngology Tourism; Endocrinology and Gastroenterology Tourism; Tourism for Immunology and Treatment of Infections; Sports Medicine Tourism.

Recreation tourism deals with health recovering resort system as well as with mental \& physical rehabilitation subsystems development in tourism. Recreation tourism correspond with above mentioned basic scientific categories that disclose essence and development principles of health treatment systems.

\subsection{Health tourism structure}

The health effects of tourism contribute to its widespread use in the complex of spa treatment. Recently, in the scientific and methodological literature, the media has been promoting such a type of tourism as medical or health-improving. Medical tourism occupies a special place in the global resort system and tourist relations. According to the man-day's indicator of stay, the share in the world tourist turnover of medical tourism is less than $1 \%$, and in the income structure - about $5 \%$, i.e. it is the most money-intensive tourism branch.

In fashion are a healthy lifestyle, active middle-aged people recreation. According to experts, consumers of this type will be the main health customers' resorts and will guarantee health and wellness tourism prosperity in the XXI century. Recently, the health tourism market is undergoing changes. Traditional sanatoriums cease to be a treatment place and recreation for the elderly and become multifunctional wellness centers for a wide range of consumers.

The chosen research topic is important and timely and relevant in connection with the practical conducting feasibility a large-scale study of the recreation and treatment market, development and implementation of resort services standards. 
The medical tourism industry has been emerging since the $1980 \mathrm{~s}$, but the history of its development goes back centuries. The healing properties of natural factors still attract patients to the resort area. The flows of tourists who travel for medical purposes, at the moment are not as numerous as for recreation and entertainment, but they are growing rapidly and their geography is expanding $[4,8]$.

The main health tourism areas in the Old World are in Central and Eastern and Western Europe. Former socialist countries have a rich tradition of resort business, have a wide range of healing natural and climatic resources, use modern highly effective disease prevention methods, treatment and rehabilitation of patients. By setting relatively low prices for spa services with a high therapeutic effect, they have gained a competitive advantage and control a larger share of the European market for health tourism.

The following resorts of world importance are located in the countries of Western Europe: Baden-Baden and Wiesbaden (Germany); Nice (France); Bath (Great Britain); Spa (Belgium) and others. Most resorts in Western Europe are concentrated in Germany, Austria and Switzerland. In Southern Europe, health tourism is poorly developed $[6,8]$. In the Ukrainian health market tourism in terms of the sanatoriums number and boarding houses with treatment, the championship belongs to Lviv and Odessa regions, which account for $45.7 \%$ of their total number nationwide $[3,7]$.

The concept of "health tourism" has no unambiguous interpretation. The simplest definition can be formulated as follows: health tourism is a trip to the resort area for health and treatment. The health tourism purpose - the integrated use of natural healing factors and physical activity for therapeutic and prophylactic purposes. It is clear that medical and health tourism is often combined through a related travel purpose and the realization of this goal through the single base use.

Based on the classification of trips, medical tourism can be conditionally attributed to tourism special types, namely tourism for medical purposes. This definition includes not only trips to the resort, but also other trips for treatment, for example, for surgery in a foreign clinic (outbound tourism). Recently, more and more foreign tourists (inbound tourism) come to Ukrainian resorts for treatment. Trips to certain category resorts of Ukrainian citizens are paid by the state. Based on this, the health tourism structure can be schematically represented as follows (Fig. 1).

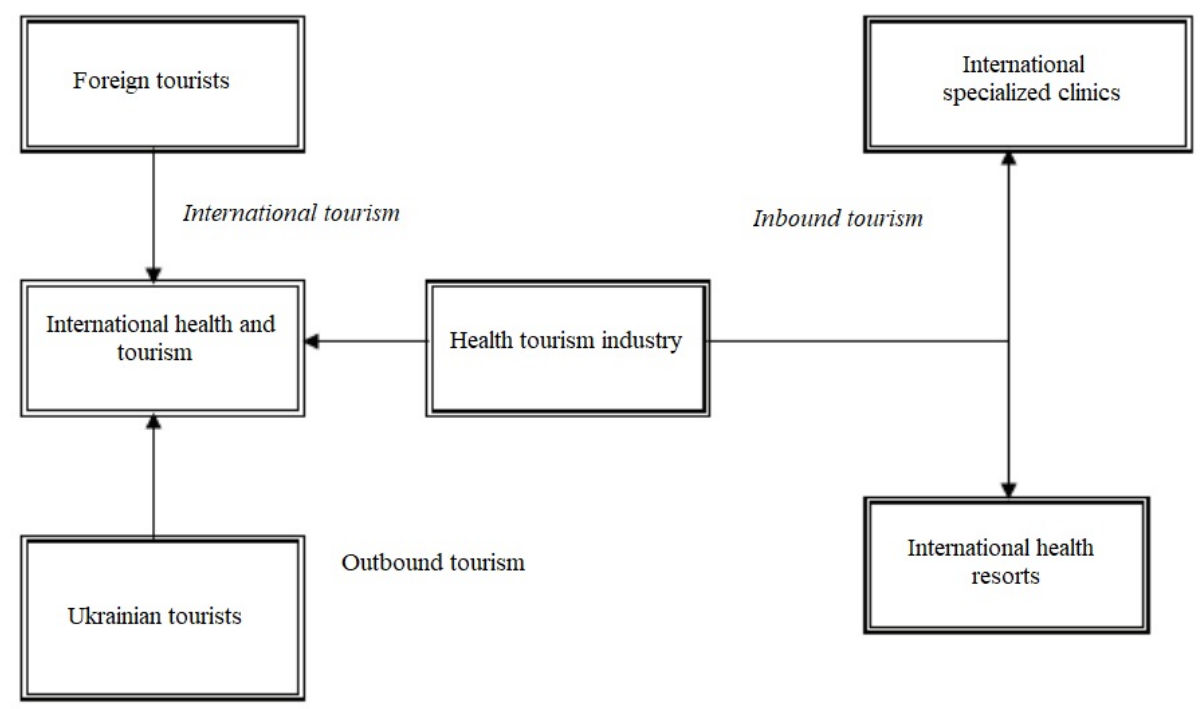

Fig. 1. The structure of international health tourism in the age of globalization. 
Health tourism has a number of defining features:

1) stay at any resort, disease regardless, must be long enough (at least three weeks), otherwise the desired health result (effect) will not be achieved;

2) treatment at resorts is expensive. This tourism type is designed mainly for wealthy clients, usually focused not on a standard set of medical services, but on an individual treatment program;

3) people of the older age group go to resorts when chronic diseases are exacerbated or the weakened organism cannot cope with daily stresses at work and in everyday life. Accordingly, these tourists choose between resorts that specialize in the treatment of a particular disease, mixed type resorts, which have a tonic effect on the body and help to restore strength.

\subsection{Worldwide management practice of formation on the product of health and recreational tourism.}

To carry out successful activities in the market of international tourist services, enterprises need a detailed and well-thought-out product policy, the task of which is the formation and implementation of the tourist offer services depending on the strategy and enterprise goals.

Recently, the market of medical and health services is changing. Traditional sanatoriums and resorts cease to be treatment place for the elderly and become multifunctional wellness centers for a wide range of consumers [5]. Modern transformations of resort centers, such as Truskavets, are due to two circumstances. This is primarily due to the changing nature of the demand for health care services. It is becoming fashionable to lead a healthy lifestyle, the people number who want to maintain good physical shape and need restorative anti-stress programs is growing. These are mostly middle-aged people who prefer active recreation and are often limited in time. According to many experts $[1,14-17$, 19-24], consumers of this type will be sanatoriums main customers in the XXI century.

The second reason for the resorts reorientation is the reduction of traditional support, including financial, from local authorities and the state. Health resorts are forced to diversify their product to enter new segments of the consumer market and attract additional customers [6]. The stay programs at the resorts are becoming more diverse and include all cultural kinds and sporting events, offer health wide range and recreation services. The International Congress on Health Tourism, held in 1999 in Italy, noted the developing importance of this tourism type for modern society and the need in this regard for largescale research of the recreation and treatment market, spa standards development and implementation [8].

The modern market of medical tourism includes accommodation companies that provide medical services (sanatoriums, spa clinics, spa hotels), travel companies (intermediary companies that sell these services) and the tourists themselves (vacationers).

Depending on the purpose of the resort can perform the following functions:

- sanatorium treatment;

- medical rehabilitation of patients;

- health recreation and disease prevention;

- cultural, medical and leisure recreation $[8 ; 10 ; 12]$.

Medical and health service in sanatoriums as a specialized process aimed at organizing recreation and improving the healthy lifestyle of the consumer (vacationer) by paying for specific services.

Due to the peculiarities of the service, certain medical forms and health services have been formed: medical and health-improving procedures, health-improving exercise, therapeutic physical training under the guidance of an instructor and independently, tourist activities (walking, short-distance tourism, travel, etc.), sun, water and air baths, moving 
games, etc. On the example of Truskavets resort, it was researched and found that medical and health programs for vacationers (tourists) provide activities that can be divided into the following groups:

1) excursion and information activities: excursions (different in subject, means of transportation and venue);

2) cultural and entertainment events: attending concerts, theaters, art festivals, folklore programs, etc.;

3) entertainment events: various competitions, animation programs, attractions, games, quizzes, auctions and holidays, visits to entertainment venues (aqua and theme parks), etc.;

4) sports and health activities: classes in various sports and training in various sports; health-improving physical education classes; massage and acupuncture; various physiotherapy; visiting the sauna, bath or pool, fitness center; organization of sports competitions, mobile competitions and games; river and sea walks; one- and multi-day hikes; rafting, yachting, dart, diving, kayaking, paragliding, horseback riding, etc.;

5) social events: evenings and meetings, forums and rallies, visits to special facilities industrial enterprises, agricultural, educational and children's institutions and other institutions; visiting families, participating in labor actions.

Concluding medical and health programs for sanatoriums in Ukraine provides the following seven stages of medical development and health products (Fig. 2).

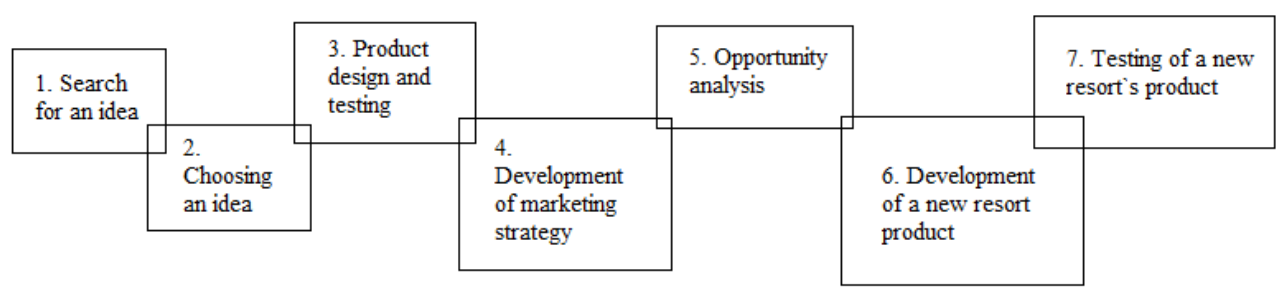

Fig. 2. The main stages of development of medical and health product

Such a complex multi-stage process as the development of a medical and health product includes:

- marketing research;

- analysis of market segments and competitors;

- proposed consumer demand;

- resort location;

- tourist services market conditions;

- assessment of the real development costs, services advertising and promotion.

The works list on medical creation and improving product (program) includes:

- market research of potential demand;

- search for partners - goods suppliers and services;

- checking the services availability and establishing the adequacy of previously received information;

- agreements preparation (contracts) on cooperation with suppliers and sellers of tourism products and negotiations;

- information and methodological support (stay programs preparation, information letters, calculations, passports of the tourist route, etc.);

- medical and improving rounds to consumers realization;

- registration of documents for travel;

- tourists direct service and control over the provision of a certain quantity and services quality. 
Tourist records play an important role in creating the stay program, as the type of clients it uses influences the structure of the health-improving tour, goal setting and choice of resort on the world map.

To attract foreign tourists, Ukrainian resorts need to address a number of funding, management and modernization issues. The basis for the formation (design) of a tourist product in Ukrainian resorts should be the latest spa technologies that improve life quality [3]. To do this, we recommend:

- to develop fundamentally new approaches to the sanatoriums activities on the basis of borrowing market management experience of international resort hotels;

- most fully meet the consumers' needs (vacationers, guests, tourists, vacationers) in rest and relaxation service during their stay at a resort [2].

One of the important medical tasks and health tourism is the development of tourism specialists' skills and abilities to design medical and health programs in sanatoriums, in accordance with established international standards. Medical construction and health programs is carried out in accordance with the principles of imperativeness and completeness, which provide for scientifically sound and specialists practice-oriented training in the activities types in sanatoriums.

The medical and health-improving model program is purposeful preparation of experts for a concrete kind activity. The design of the medical complex and health-improving program is based on block-modular technology. The module is created for service consumers [1;9].

Creation and introduction of modules in domestic resorts practice will allow, in our opinion, to reveal advantages, formation efficiency of medical and improving programs for each vacationer separately $[4,9]$.

Based on the study of the international experienced spa resorts, in order for sanatoriums in Ukraine to more actively implement progressive international principles and health tourism standards, we have developed the following generalized recommendations for the domestic sanatoriums management [25-28]:

- to develop variable season tickets for complex medical and health services (with the number of classes from 1-2 to 3-4 times a week);

- to pay attention to drawing up (formation) individual programs of employment with the subsequent instructor control;

- in the gym to conduct strength and aerobic training, personal training;

- to offer various types of aerobics for different preparation levels of vacationers (clients), as well as combined training for men and women, aimed at developing flexibility and other qualities;

- to introduce aqua aerobics in the pool for different age groups (at different depth levels);

- to improve the system of medical and health services with new programs for a specific material and technical base;

- to intensify the short-distance tourism organization in the conditions of sanatorium treatment;

- to systematically improve the network and develop new tour routes for hiking, cycling, equestrian tourism, routes, health tourism, Nordic walking;

- when developing and building a new sanatorium medical and health structure to take into account the interests and popularity rating of each service;

- to develop walking medical tourism, hippotherapy;

- pay special attention to the use of material, sanatorium technical base and health complex during the "dead season".

The introduction social consequences of new approaches to health tourism in the sanatoriums practice are as follows: 
1) formation of innovative functional subsystems "relaxation" and "active recreation" within the national health care system;

2) increasing the domestic sanatorium's profitability and resort industry by introducing into its work the international tourism business laws and individual service processes quality management technologies.

This requires the development of new organizing ways the service in order to fully meet not only the narrow medical, but also in general relaxation and recreation needs of consumers during their stay at the resort [11-13, 18, 29-30].

\section{Conclusions}

In modern economic conditions, any company independently reveals the formation directions and implementation of marketing product policy in recreation and health tourism systems. Taking into account the peculiarities of each individual product type, it is impossible to develop a single approach to the formation of strategy, product policy tactics and structure. As a rule, its main components include: new products planning and development; product life cycle management; products determination of the optimal range; strategies formation and implementation for packaging and goods design; service; creating and maintaining a sustainable products positive image.

Today, in conditions of fierce competition, it is the properties and product characteristics that determine the market direction and the entire production policy of the enterprise. All activities related to the product, i.e., its creation, production and improvement, sales in the markets, service and pre-sales service, development of promotional activities, as well as goods withdrawal from production, occupy a central place in all manufacture activities and are part of its product policy.

The issue of effective formation in product policy is the basis of the enterprise, its profits source, further operation and development prospect.

\section{References}

1. Illiashenko, S.M., \& Strielkowski, W. (eds.). (2016). Managing economic growth: marketing, management, and innovations. Prague: Prague Institute for Qualification Enhancement.

2. Intmedtourism (2020). Global agency Intmedtourism. http://www.intmedtourism.com

3. State Regulatory Service of Ukraine (2020). http://www.dkrp.gov.ua

4. Zorin, I.V. (2001). Tourism. M.: Soviet sport.

5. Malskaya, M., \& Rutinsky, M. (2008). Health-improvement tourism. Tourism in the international and national dimensions. History and modernity. Lviv: LNU Publishing Center. I. Franko.

6. Mikhno, I., Koval, V., Shvets, G., Garmatiuk, O., \& Tamošiūnienė, R. (2021). Green Economy in Sustainable Development and Improvement of Resource Efficiency. Central European Business Review, 10(1), 99-113. https://doi.org/10.18267/j.cebr.252

7. Stafiychuk, V.I. (2008). Recreation. Kyiv: Alterpress.

8. Fedorchenko V.K., Pazenok V.S., Kruchek O.A. (2013) Science of Tourism: conceptual base the theory of tourism. Academy, Kyiv, Ukraine

9. Schmalen, G. (2005). Fundamentals and problems of enterprise economics. M: Finance and Statistics.

10. Medical tourism guide (2020). Health tourism. https://health-tourism.com 
11. Rajagopal, P. (2007). Marketing Dynamics: Theory and Practice. New Delhi, India: New Age International.

12. Thomas, S. (1970). Fundamentals of Recreation. Harpers \& Row, Library of Congress.

13. Hutsaliuk, O., Koval, V., Tsimoshynska, O., Koval, M., Skyba, H. (2020). Risk Management of Forming Enterprises Integration Corporate Strategy. TEM Journal, 9(4), 1514-1523. https://doi.org/10.18421/TEM94-26

14. Arsawan, I.W.E., Koval, V., Rajiani, I., Rustiarini, N.W., Supartha, W.G., \& Suryantini, N.P.S. (2020). Leveraging knowledge sharing and innovation culture into SMEs sustainable competitive advantage. International Journal of Productivity and Performance Management (in press). https://doi.org/10.1108/IJPPM-04-2020-0192

15. Prokopenko, O.V. (2011). Consumer choice types in marketing of ecological innovations. Actual Problems of Economics, 16(2), 109-116.

16. Koval, V., Kovshun, N., Plekhanova, O., Kvitka, S., \& Haran, O. (2019). The role of interactive marketing in agricultural investment attraction. 19th International Multidisciplinary Scientific GeoConference SGEM 2019, 19(5.3), 877-884. https://doi.org/10.5593/sgem2019/5.3/S21.111

17. Mykytenko, V. (2020). Identification and grouping of threats and risks to sustainable $\begin{array}{llll}\text { management. Studia } \quad \text { Universitatis } & \text { Moldaviae, } & \text { 7, }\end{array}$ https://doi:10.5281/zenodo.4461085

18. Kostetska, K. (2018). Trends of development of administrative management of recreational and tourist nature production in domestic and international practice. Economics, Ecology, Socium, 2(1), 111-121. https://doi.org/10.31520/26167107/2018.2.1-10

19. Prokopenko, O.V., Shkola, V.Y., Domashenko, M.D., \& Prokopenko, M.O. (2015). Conceptual grounds to form motivational constituent of the international ecological policy. Marketing and Management of Innovation, 4, 245-259.

20. Mykytenko, V.V., \& Lytsur, I.M. (2020). Threats and risks of implementation of the spatial model of natural resource management. Balanced nature management, 1, 11-20. https://doi.org/10.33730/2310-4678.1.2020.203916

21. Zamula, I., Tanasiieva, M., Travin, V., Nitsenko, V., Balezentis, T., \& Streimikiene, D. (2020). Assessment of the Profitability of Environmental Activities in Forestry. Sustainability, 12(7), 2998. https://doi.org/10.3390/su12072998

22. Kvach, Y., Koval, V., \& Hrymaliuk, A. (2018). Tourism and hospitality industry in the context of global economic development. Economics. Ecology. Socium, 2(4), 11-21. https://doi.org/10.31520/2616-7107/2018.2.4-2

23. Bazaluk, O., Yatsenko, O., Zakharchuk, O., Ovcharenko, A., Khrystenko, O., \& Nitsenko, V. (2020). Dynamic Development of the Global Organic Food Market and Opportunities for Ukraine. Sustainability, 12(17), 6963. https://doi.org/10.3390/su12176963

24. Ramazanov, S. (2020). Development, Management and Forecasting in a Green Innovative Economy, Based on the Integral Dynamics Model in the Conditions of 'Industry-4.0'. ACCESS Journal: Access to science-business-innovation in digital economy, 1(1), 9-29.

25. Lukjanova, J. (2019). Problems and trends of regional tourism development in Latvia. Economics Ecology Socium, 3(1), 1-11. https://doi.org/10.31520/2616-7107/2019.3.1-1

26. Bilan, Y., Zos-Kior, M., Nitsenko, V., Sinelnikau, U., \& Ilin, V. (2017). Social component in sustainable management of land resources. Journal of Security and Sustainability, 7(2), 107-120. https://doi.org/10.9770/jssi.2017.7.2(9) 
27. Zamlynskyi, V., Yurchenko, N., \& Haltsova, O. (2018). Features of a complex marketing approach in management of the tourism industry. Economics, Ecology, Socium, 2(4), 64-76. https://doi.org/10.31520/2616-7107/2018.2.4-7

28. Demianchuk, M. A., Bezpartochnyi, M., Filipishyna, L., \& Živitere, M. (2021). The Model of Achieving a Balanced Balance between Economic Efficiency and EcologicalSocial Responsibility of Digitalized Enterprise, 14(1), 63-70. https://doi.org/10.22094/JOIE.2020.677817

29. Pogodayev, S. E. (2013). Marketing of works as a source of the new hybrid offerings in widened marketing of goods, works and services. Journal of Business \& Industrial Marketing, 28(8), 638-648. https://doi.org/10.1108/jbim-04-2012-0069

30. Romanenko, Y. O. (2016). Place and role of communication in public policy. Actual Problems of Economics, (2), 25-31. 